\title{
APLIKASI PEMBELAJARAN DI JENJANG PENDIDIKAN DASAR BERBASIS RAMAH OTAK MELALUI BRAIN DEVELOPMENT STRATEGY
}

\author{
Widodo Winarso* \\ *Dosen Jurusan Tadris Matematika FITK IAIN Syekh Nurjati Cirebon \\ Email:widodo_ppsstain@yahoo.co.id
}

\begin{abstract}
ABSTRAK
Terkait dengan implemtasi kurikulum yang menyangkut pendidikan anak di tingkatan Sekolah Dasar. Pola pendidikan anak di tingkat ini dikenal dengan istilah Pembelajaran tematik terpadu. Hal ini berbeda dengan pembelajaran ditingkatan kelas di atasnya, yang secara khusus mempelajari ilmu dari berbagai disiplin yang berbeda. Pada pembelajaran di tingkat ini semua disiplin ilmu diajarkan tidak secara mandiri, namun secara terpadu yang dikemas dalam tematema tertentu. Bagian inilah yang menarik untuk dikaji. Pada pembelajaran model ini, peserta didik sudah tidak perlu lagi memikirkan sedang belajar mata pelajaran apa, namun peserta didik belajar tentang apa secara holistik. Pembelajaran terpadu menggunakan tema sebagai pemersatu kegiatan pembelajaran yang memadukan beberapa mata pelajaran sekaligus dalam satu kali tatap muka, untuk memberikan pengalaman yang bermakna bagi peserta didik. Karena peserta didik dalam memahami berbagai konsep yang dipelajari selalu melalui pengalaman langsung dan menghubungkannya dengan konsep lain yang telah dikuasainya. Pembelajaran tematik diyakini sebagai salah satu model pembelajaran yang efektif (highly effective teaching model), karena mampu mewadahi dan menyentuh secara terpadu dimensi emosi, fisik, dan akademik di kelas atau di lingkungan sekolah. Model pembelajaran tematik ini terbukti secara empirik berhasil memacu percepatan dan meningkatkan kapasitas memori peserta didik (enhance learning and increase long-term memory capabilities of learners) untuk waktu yang panjang. Model pembelajaran tematik memiliki perbedaan kualitatif (qualitatively different) dengan model pembelajaran lain. Model pembelajaran ini mengoptimasi lingkungan sebagai kunci dalam menciptakan kelas yang ramah. Kondisi belajar dimana aktifitas belajar yang terjadi melibatkan subjek belajar secara langsung, mengoptimasi semua sumber belajar, dan memberi peluang untuk mengeksplorasi secara luas kemampuan kognitif sisiwa melalui aplikasi pembelajaran ramah otak.
\end{abstract}

Kata kunci : Pembelajaran, Ramah Otak, Brain Development Strategy 


\section{A. PENDAHULUAN}

Pendidik menjadi pusat perhatian karena sangat besar peranannya dalam setiap usaha peningkatan sumber daya manusia. Tak ada usaha inovatif dalam pendidikan yang dapat mengabaikan peranan pendidik. Berbagai penelitian diberbagai negara mengungkapkan bahwa pendidik merupakan penentu paling besar terhadap prestasi belajar. Peranan pendidik semakin penting di tengah keterbatasan sarana dan prasarana seperti di negara-negara berkembang.

Isu klasik yang muncul selama ini ialah usaha yang paling tepat untuk meningkatkan mutu pendidikan melalui peningkatan mutu pendidik. Berbagai kebijakan dilakukan Pemerintah, misalnya melalui penataran, pendidikan/penyetaraan, atau melalui pelatihan. Selain kondisi tersebut, perlu dicermati perkambangan isu lain yakni dilakukan pula peningkatan kesejahteraan (terutama gaji) bagi pendidik agar lebih termotivasi untuk bekerja. Sesungguhnya hal tersebut tidak menjamin $100 \%$ untuk peningkatan mutu pendidik, kalau pendidik itu sendiri tidak memiliki motivasi dan inovasi untuk mengubah pendidikan dan pembelajaran ke arah yang lebih baik.

Membicarakan tentang pendidik dan dunia kependidikan ibarat memperbaiki benang kusut. Langakah awal apa yang harus ditempuh untuk memperbaiki sistem pendidikan di negeri ini. Hal tersebut, memberikan kebingungan secara kolektif bagi pengambil kebijakan. Tentunya jawaban atas permasalahan tersebut tergantung pada sudut pandang mana yang digunakan dalam melihat pendidik. Untuk meningkatkan kualitas pendidik harus dilakukan melalui faktor internal dan eksternal.

Pertama faktor eksternal, pendidik harus banyak diberi pendidikan dan pelatihan berbagai keterampilan mengajar (model pembelajaran) dari para penyelenggara pendidikan baik pemerintah maupun swasta yang konsen pada perbaikan di dunia pendidikan. Kedua faktor internal, pendidik harus lebih kreatif dan inovatif, serta banyak menyerap informasi tentang perkembangan dunia pendidikan terutama perkembangan model pembelajaran. Untuk memperbaiki dan meningkatkan mutu proses dan hasil pembelajaran di 
samping juga menyelaraskan dan menyerasikan proses pembelajaran dengan pandangan-pandangan dan temuan-temuan baru diberbagai bidang model pembelajaran senantiasa dimutakhirkan, diperbaharui, dan dikembangkan oleh berbagai kalangan khususnya kalangan pendidik.

Sejalan dengan konsep tersebut, menjadi pondasi dasar bagi para pendidik untuk melakukan pembenahan pembelajaran. Pendidikan dasar menjadi tumpuan awal dalam pembentukan perubahan generasi suatu bangsa. Dengan pelaksanaan kurikulum 2013 yang salah satunya menggunakan model pembelajaran tematik. Pendidik diberikan kesempatan yang luas untuk berinovasi dan berkreasi dalam mengajar disekolah. Kreatifitas belajar peserta didik dapat terbangun dengan melaksanakan model pembelajaran tersebut. Selain itu, pertimbangan lain yang harus dijadikan dasar bagi pendidik yakni pertimbangan perkembangan otak peserta didik. Kesesuian antara kapasitas memori yang dimiliki dengan muatan pembelajaran perlu dipahami oleh peserta didik. Sehingga muatan pembelajaran akan tersimpan dalam memori jangka panjang dan materi pembelajaran pun memiliki nilai penting (pembelajaran bermakna) bagi peserta didik.

\section{B. POTENSI OTAK PADA PRIBADI PESERTA DIDIK}

Pada perkembangan dunia pendidikan dewasa ini, pendidik dituntut untuk mengetahui kehebatan otak. Dengan mengetahui kehebatan otak, penddik akan menyadari dan meyakini bahwa otak sebagi nikmat yang luar biasa dan sangat menakjubkan. Keyakinan ini akan memotivasi pendidik yang berikutnya ditularkan pada para peserta didik untuk mensykuri apa yang dimilikinya.

Pandangan terhadap wujud sukur dapat dikuatkan melalui beberapa para ahli. Misalnya, dalam kitab Madarij as-Salikin (2:247), buah karya Ibnu Qoyim Al-Juziah, Syeikh Abu Ismail al-Harawi, mengatakan bahwa syukur itu sebuah nama untuk mengetahui nikmat. Cara mengetahui nikmat merupakan jalan untuk mengetahui Pemberi nikmat”. Ibnu Qoyim mengomentarinya bahwa mengetahui nikmat merupakan fondasi (rukun) syukur. Beliau melanjutkan pandanganya yakni mengetahui nikmat 
merupakan pondasi yang paling utama, karena tidak mungkin ada syukur, tanpa mengetahui nikmat. Ternyata syukur pun ada rukunnya, mirip seperti pada shalat dan ibadah-ibadah mahdhoh lainnya. Dalam kitab lain (Fath alMajid:452) Ibnu Qoyim mengatakan bahwa barang siapa yang tidak mengetahui nikmat, lebih-lebih jahil atas nikmat itu, maka ia tidak akan pernah mensyukurinya. Syeikh Abdurrahman (Fath al-Majid:65 dan 452), ketika mengomentari kitab Tauhid Abdul Wahab, yang menjadi rujukan utama kaum Wahabi di bidang tauhid, mengatakan pula bahwa syukur itu tidak akan tegak, kecuali bila dibangun di atas tiga rukun (fondasi); pengakuan atas nikmat, menghubungkannya dengan Pemberi nikmat, dan menggunakan sesuai dengan tuntutan (fungsi) nikmat.

Dari berbagai organ tubuh manusia, otak merupakan organ yang paling kompleks. Hingga saat ini, penelitian tentang otak terus berkembang. Dave Meier (2002:81) mengatakan bahwa penelitian otak yang dilakukan dalam 25 tahun terahir lebih banyak dari pada dalam seluruh sejarah manusia digabung menjadi satu.

Otak manusia memiliki kapasitas (kemampuan yang bersifat bawaan) sangat besar untuk belajar karena secara proporsional manusia memiliki area otak yang selalu siap untuk belajar sesuatu yang baru. Area otak itu dikenal sebagai otak berfikir atau otak belajar (the learning brain), dan dalam istilah Neurologist dinamakan neocortex.

Menurut Sufyan Ramadhy, dkk (2001:29-30) bahawa kemampuan Neokortex pada manusia memberikan kemampuan manusia untuk berfikir, persepsi, berbicara, berbahasa, berperilaku yang beradab dan berbudaya, belajar atau mempelajari sesuatu yang baru, imajinasi kreatif, memproses informasi, merasakan, bergerak, dan fingsi-fungsi luhur lainnya.

Berdasarkan hasil penelitian mutakhir menunjukkan bahwa otak manusia terdiri dari milyaran sel aktif yang disebut neuron. Gordon Dryden (2000:114) bahwa otak manusia memiliki 100 miliar sel aktif, masing-masing memiliki hingga 20.000 koneksi. Selain itu, menyatakan bahwa sejak harihari pertama kehidupan, sel-sel tersebut membentuk koneksi belajar (atau 
sinapsis) dengan kecepatan yang luar biasa yakni 3 miliar perdetik. Koneksi tersebut adalah kunci dari kekuatan otak.

Masing-masing sel aktif dapat membuat jaringan sampai 20.000 sambungan tiap detik. Hal menakjubkan lainya adalah pada hari-hari pertama kehidupan manusia, otak manusia dapat berkembang melalui proses belajar alamiah dengan kecepatan 3 miliar sambungan perdetik. Sambungansambungan inilah yang menjadi kunci kekuatan otak. Untuk sambungansambungan ini, para ahli neurologist menyebutnya dengan koneksi atau sinapsis. Kecanggihan dan kecepatan sel-sel otak dalam melakukan hubungan (koneksi), dapat dibuat perbandingan dengan 3 hari pertama dalam perjalanan Angkasa di atas permukaan Mars pada tahun 1997, seperti yang diungkapkan Gordon bahwa jutaan pengguna Internet membentuk 200 juta sambungan untuk mengikuti perkembangan perjalanan angkasa tersebut. Sedangkan otak manusia mampu membuat jaringan 15 kali lebih besar dalam satu detik dibanding dengan jaringan internet di seluruh dunia dalam waktu 3 hari.

Bayangkan 100 milyar koneksi listrik yang terjadi di dalam otak sekarang ini. Bayangkan setiap orang di dunia (kira-kira llima setengah milyar manusia) bicara di telpon satu sama lain pada saat bersamaan. Tetapi untuk memperoleh gambaran betapa dahsyatnya yang terjadi di dalam otak. Suruhlah lima setengah milyar orang itu berbicara pada delapan belas pesawat telpon masing-masing. Suruh mereka berbicara satu sama lain pada saat yang bersamaan.

Jika setiap neuron hanya dapat menyentuh dua neuron lainnya, jumlah kemungkinan konfigurasi dalam otak adalah dua pangkat 100 milyar. Bilangan sebesar itu memerlukan waktu 100 tahun untuk ditulis dengan kecepatan satu angka perdetik. Dalam kenyataannya, karena setiap neuron berhubungan dengan setiap neuron lainnya, kemungkinan konfigurasinya mustahil dipahami.

Robert Ornstein dalam Gordon (2003:115) mengatakan bahwa jumlah koneksi yang mungkin, kemungkinan lebih banyak dari pada jumlah atom di jagat raya ini. Hal ini menunjukkan kemampuan dan kapasitas otak yang luar 
biasa, sehingga otak manusia mampu menghapal seluruh atom yang ada di alam raya.

Untuk lebih konkretnya, Agus Nggermanto (2002:38) menjelaskan bahwa kemampuan memori otak manusia adalah 10800 (angka 10 dengan 0 sebanyak 800 di belakangnya). Sedangkan jumlah atom yang ada di belahan bumi ini sekitar 10100 (angka 10 dengan 0 sebanyak 100 di belakangnya).

Kemapauan otak peserta didik yang luar biasa dapat dimanfaatkan dengan maksimal yakni dengan memebrikan stimulus terhadap peserta didik berupa kemampuan koneksi. Peserta didik mampu mengkoneksikan dari pengetahuan yang satu dengan pengetahuan yang lain.

Selain itu, Dave Meier (2002:286) menyatakan bahwa menghubungkan adalah intisari kecerdasan, apakah itu antara neuron-neuron di dalam otak atau para pembelajar dalam suatu komunitas belajar. Semakin banyak kesalingterkaitan yang ada, semakin banyak pula kecerdasan yang hadir.

Peserta didik harus banyak melakukan koneksi dengan cara menghubungkan sel otak dengan berbagai hal, semakin banyak hubungan (koneksi) yang terjadi, semakin banyak pula kecerdasan yang terbentuk. Dan sebaliknya, bila sel otak tidak melakukan koneksi dengan berbagai hal, semakin kurang kecerdasan yang berkembang, bahkan bisa jadi semakin lemah dan rusak. Untuk melakukan koneksi, siapapun mampu melakukannya. Orang yang bukan pembelajar formal pun dapat melakukan, lebih-lebih yang tercatat sebagai pembelajar secara formal. Memang benar diakui oleh para ahli, bahwa manusia akan kehilangan sebagian sel saraf otak bersamaan dengan tambahnya usia. Seseorang yang berusia lanjut mempunyai jumlah sel saraf lebih sedikit di banding dengan sel saraf bayi yang baru lahir.

Perlu di perhatikan, bahwa kapasitas dan kemampuan otak, bukan hanya tergantung pada jumlah sel saraf aktif, melainkan pada jumlah dan kualitas koneksi (sinapsis) yang terjadi. Hal tersebut dapat tumbuh dan berkembang sepanjang umur manusia. Seperti yang dinyatakan Sufyan Ramadhy (2001:38-39) bahwa kekuatan otak (brain power) itu tergantung kepada jumlah dan kualitas sinapsis yang terbentuk melalui proses belajar. 
Secara fisiologi, otak sangat mirip dengan milik orang lain, bahkan dengan pemikir-pemikir cemerlang sekalipun seperti Albert Einstein, Leonardo Da Vinci, Al-Khowarizmi, Al-Gozali, Ibnu Rusyd, Habibi, Nurholis Majid, Amin Rais, dan orang-orang terkenal lainnya. Hal ini menunjukkan bahwa secara fisiologis, otak manusia memiliki peluang yang besar untuk berkembang dan mencapai keberhasilan. Peserta didik hanya perlu belajar bagaimana mengelola dan membimbingnya untuk mencapai prestasi gemilangnya. Kapasitas otak sangat tak terbatas dan penelitian otak terus berkembang sehingga penemuan berbagai kecerdasan mulai bermunculan. Penemuan mutahir dari para ahli dan peneliti, ternyata di dalam otak masih lebih banyak kekuatan yang bersifat potensialnya ketimbang yang aktual.

Perkiraan di atas bukan menggambarkan kecerdasan peserta didik yang menurun, melainkan lebih menggambarkan kemampuan peserta didik sekarang yang makin canggih dalam mengukur potensi otak Bukan karena kecerdasan manusia menjadi turun secara drastis, melainkan cerminan bahwa sekarang ini banyak ditemukan kekuatan potensial otak yang belum dimanfaatkan.

\section{TEORI OTAK}

Untuk mengenal dan memahami sebahagian teori tentang otak. Sebelum mengetahui dan memahami teori otak secara mendalam, perlu adanya sebuah perkenalan tingkat dasar. Pengenalan teoritis tentang otak dalam tulisan ini, sudah barang tentu sangat sederhana, akan tetapi sangat menunjang bagi dunia pendidikan dan peningkatan efektivitas pembelajaran di Sekolah dasar.

Cara kerja otak dalam belajar, memang masih banyak hal yang belum terungkap, tetapi di sisi lain, banyak juga yang sudah ditemukan oleh para ahli. Teori-teori yang sudah ditemukan oleh para ahli, sangat bermanfaat dan merupakan kontribusi berharga dalam memperkaya pemahaman tentang cara otak belajar. Hasil para ahli dan peneliti, pandangannya tidak terlalu bertentangan bahkan lebih saling melengkapi dan saling mendukung. Dengan 
mempelajari teori tentang otak, berarti sudah mulai menjelajahi kemapuan peserta didik (potensi otak).

\section{Teori Otak Triune (Three In One)}

Otak manusia adalah massa protoplasma yang paling kompleks yang pernah dikenal di alam semesta ini. Inilah satu-satunya organ yang sangat berkembang sehingga ia dapat mempelajari dirinya sendiri. kata (Bobbi De Porter dan Mike Hernacki, 2001:26).

Walaupun system otak sangat kompleks, akan tetapi pribadi peserta didik masih dapat dipelajari. Untuk menghilangkan kesan rumit, para ahli membagi lapisan otak dengan tujuan untuk penyederhanaan dan mempermudah dalam pemahaman. Lahirlah gagasan baru yang disebut teori Three in One tentang otak manusia.

Menurut teori ini, otak manusia mempunyai tiga lapisan otak, masingmasing mempunyai fungsi spesialisasi terpisah meskipun tetap ketiganya saling berhubungan. Ketiga lapisan otak ini saling terkait dalam satu organisme menyeluruh dan saling terlibat dalam tugasnya dengan cara yang komplek, rumit, tapi menentukan. Lapisan otak manusia terdiri dari tiga bagian dasar yang berbeda, yaitu otak reptil, sistem limbik, dan otak neokortek yang disebut dengan otak belajar.

\section{a. Otak reptil}

Disebut otak reptil, karena mirip dengan otak reptile berdarah dingin.

Disebut juga dengan batang otak, karena letaknya berada pada batang otak. Manusia dan binatang merayap memiliki unsur kesamaan yaitu kepemilikan otak reptile. Inilah tingkat kecerdasan terendah dan paling sederhana dari spesies manusia.

Proses pembelajaran tradisional-konvensional, cenderung menekankan fungsi reptile yang berlebihan. Seperti belajar menghapal, meniru pendidik secara membuta, pendidik sebagai pusat kekuasaan (teacher centerd). Hal ini juga nampak pada dominasi pendidik yang berlebihan, pembelajar harus mengikuti rutinitas dan contoh format yang ditetapkan, dan pembelajar dianggap pelayan yang harus patuh 
secara pasif. Pembelajar digerakkan oleh semangat mempertahankan diri seperti takut kegagalan, nilai kecil, tidak naik kelas dan sebagainya. Proses pembelajaran seperti ini kurang memperhatikan pada perasaan dan ikatan sosial di lingkungan belajar, tanpa ada usaha membimbing pembelajar yang mengarah pada cara-cara berkreasi, cara melahirkan ide-ide cemerlang, memecahkan masalah, dan berfikir mandiri.

Pendidik perlu mengembangkan kecerdasan yang lain dan lebih tinggi, yaitu kecerdasan yang berpusat pada system limbic dan neokortek. Kecerdasan tingkat tinggi ini diperlukan untuk membimbing dan mengarahkan sebagian fungsi reptile agar lebih berkembang secara wajar dan normal.

Dalam keadaan bahaya, setres atau tertekan, dan terancam, otak reptile bekerja dengan cepat, jantung berdegup lebih cepat, pernapasan lebih cepat pula, perasaan negative, dan perhatiannya adalah terpusat hanya untuk menyelamatkan diri. Pada situasi aman, bebas dari tekanan dan ancaman, otak reptile bekerja secara normal. Sedangkan dalam situasi yang sebaliknya, peserta didik tidak dapat bekerja dengan normal. Konsentrasinya terpusat untuk menyusun strategi dalam menghadapi bahaya atau ancaman. Strategi tersebut adalah melawan ancaman bahaya, menyerah dengan penuh rasa takut, atau 'melarikan diri. Agar proses pembelajaran berjalan dengan efektif dan pemikiran kreatif menjadi aktif, otak reptile ini harus dikondisikan aman. Dalam kondisi aman, otak reptile mampu bekerja dengan baik dan mendukung bagian otak lain untuk belajar. Bahkan, dalam kondisi aman memungkinkan mendorong seluruh bagian otak menjadi berfungsi dan berani mengungkapkan gagasa-gagasan baru yang kreatif inovatif.

Sementara dalam kondisi terancam, otak reptile akan memberontak dengan memanfaatkan strategi 'melawan' atau 'lari'. Dalam pengertian otak dipaksa belajar karena ada ancaman, belajarnya bukan sungguhan 
akan tetapi hanya untuk bertahan, atau peserta didik akan lari dan tidak belajar sama sekali. Termasuk hal-hal yang dapat mengancam kestabilan otak reptile adalah perasaan takut baik takut pada pendidik, dicemoohkan, ditertawakan, dan ketakutan-ketakutan lainnya. Dalam kondisi seperti ini, otak akan berontak dengan strategi 'melawan' atau 'melarikan diri'.

Belajar bukan karena takut, seperti takut nilai kecil, tidak naik kelas, tidak lulus, atau ketakutan lain. Tetapi menjadikan belajar karena terdorong oleh rasa ingin tahu (curiosity) yang telah melekat dan mengakar secara mendalam pada jiwa peserta didik.

\section{b. Otak Mamalia (Sistem Limbik)}

Disebut otak mamalia karena mirip dengan otak mamalia berdarah panas lainnya. Letaknya berada dibagian tengah otak. Otak limbic, memainkan peran besar dalam mengendalikan emosi dan perasaan, sehingga sistem limbic ini dikenal dengan otak emosional (The Emotional Brain). System limbic sangat berfungsi dalam penyimpanan perasaan peserta didik, pengalaman yang menyenangkan, memori, dan kemampuan belajar peserta didik. Dengan system kerja yang kompleks, peserta didik juga mengendalikan bioritmenya, seperti pola tidur, lapar, haus, tekanan darah, detak jantung, gairah seksual, system kekebalan, dan yang lainnya.

Peserta didik harus melibatkan fungsi limbic dalam pembelajaran. Emosi, sebagaimana dibenarkan oleh penelitian dan akal sehat, juga pengalaman yang melekat, sangat berpengaruh pada kualitas dan kuantitas belajar.

Sufyan Ramadhy (2001:32) mengatakan bahwa penelitian mutahir menunjukkan bahwa system limbic ini berperan dalam penyatuan (integrasi) pemikiran rasional dan energi emosi, yang artinya menyempurnakan proses berfikir manusia. Hal serupa dinyatakan oleh Gardon Dryden (200:125) yang mengatakan bahwa pusat emosi otak berhubungan erat dengan system penyimpanan memori jangka 
panjang. Itulah sebabnya peserta didik semuanya dapat mengingat dengan mudah informasi apapun yang memiliki muatan emosi yang tinggi. Sebagai pengendali emosi, system limbic juga memberikan kontribusi yang mendasar terhadap proses belajar. Sistem limbic melakukan peran vital dalam meneruskan informasi yang diterima ke dalam system memori. Perasaan senang, gembira dapat mempercepat proses pembelajaran. Sebaliknya perasaan negative akan memperlambat belajar, bahkan menghentikannya sama sekali.

Perasaan atau emosi positif dapat digambarkan misalnya optimis lawan dari pesimis, sabar dan tidak jengkelan, tekun, ulet dan tidak merasa bosan. Siap menghadapi tantangan belajar, siap menyingkirkan semua rintangan dan gangguan yang mengacaukan mental dalam belajar Pada situasi dimana peserta didik merasa jenuh dan membosankan, otak limbic akan bekerja dengan tidak optimal, bahkan negative, sehingga fokusnya berkonsentrasi pada hal-hal di luar yang sedang dihadapi. Sebaliknya, bila kondisi emosi positif, maka system limbic akan terpancing dan tergugah sehingga proses pembelajaran akan lebih efektif dan mendukung otak neokorteks lebih kreatif. Untuk kepentingan belajar, usahakan system limbic ini dalam keadaan normal, dalam pengertian emosi berada dalam kondisi positif.

\section{c. Otak Neokorteks}

Otak neokorteks atau Cortex Cerebi dikenal sebagai otak berfikir atau otak belajar (The Learning Brain). Otak ini merupakan otak tingkat tinggi dalam system otak peserta didik. Sesuai dengan namanya (The Learning Brain), otak ini berfungsi mengendalikan hal-hal yang bersifat rasional sehingga disebut juga sebagai otak rasional.Otak ini merupakan lapisan terluar dari bagian otak yang menutupi otak bagian dalam yaitu system limbic. Otak neokorteks merupakan pusat kecerdasan manusia yang tidak di miliki oleh mahluk lain. Otak ini membuat manusia dapat belajar, berfikir, berbicara, menulis, mendengar, melihat, memecahkan masalah yang rumit, berhitung, 
merencanakan masa depan, mencipta, kreatif, berbudaya, dan nilainilai luhur lainnya.

Hal terpenting bagi pendidik terhadap peserta didik adalah memandang ketiga aspek otak ini bukan dari demensi lokasi fisiknya, melainkan sebagai pusat kliring untuk fungsi-fungsi khusus. Tidak satupun dari ketiga pusat kliring ini yang bekerja sendiri-sendiri, semuanya mempunyai hubungan dengan pusat kliring lainnya untuk meminta bantuan guna menjalankan fungsi mereka. Di dalam otak, sepanjang waktu, terjadi pertukaran energi dan saling membantu yang berlangsung secara terus menerus. Danah Johar (2001:39) mengatakan bahwa berfikir dengan jaringan saraf kompleks yang berjalinan diseluruh organisme. Jaringan-jaringan saraf merupakan bagian tak terpisahkan dari kecerdasan yang dimiliki.

\section{Teori Otak Kiri Dan Kanan}

Ketiga lapisan otak (Three in One) manusia terdiri dari dua bagian, belahan otak kanan dan otak kiri. Masing-masing memiliki spesialisasi fungsi meskipun tetap melakukan jalinan ineraksi dan kejasama yang solid di antara keduanya.

Otak kiri memainkan peran dalam pemrosesan hal-hal yang bersifat 'akademis' dan logis seperti logika, matematika, kata-kata. Model berfikirnya urut, linear dan rasional. Dengan mengoptimalkan otak belahan kiri, peserta didik mampu menyelesaikan perhitungan yang rumit sekalipun, mampu menyusun silogisme sebagai alat untuk menarik kesimpulan.

Sedangkan otak kanan berurusan dengan aktivitas kreatif yang berkaitan dengan irama, rima, musik, gambar, dan imaginasi. Model berfikirnya acak, tidak teratur, holistik, intuitif, dan imaginative. Kemampuan otak kanan, mendorong manusia untuk lebih kreatif mencari altrenatif dalam menyelesaikan masalah, mampu berfikir intuitif dan melakukan imajinasi atau visualisasi (membuat bayangan dalam bentuk gambaran mental). Kedua belahan otak kiri dan kanan dihubungkan oleh suatu system 
jaringan yang disebut corpus collasum yang merupakan system saklar yang sangat rumit dengan melibatkan ratusan juta_kabel_neuron aktifnya. Secara fisiologis, corpus collasum ini berfungsi sebagai mediator pengiriman informasi antara kedua belahan otak. Melalui mediator tersebut, kedua belahan otak dapat melakukan kerja sama dalam pengiriman informasi, kolaborasi, dan integrasi. Sebagai mediator, secara constant menyeimbangkan pesan-pesan yang datang, menggabungkan gambar-gambar yang abstrak dan holistic dengan pesan-pesan yang konkrit dan logis.

Contoh sederhana bagaimana kedua belahan otak yang berbeda dapat bekerja sama secara harmonis dan terpadu, adalah ketika Anda sedang asyik mendengarkan sebuah lagu kenangan. Otak sebelah kiri akan memproses syairnya, karena ia berbentuk kata-kata. Sedang otak kanan memproses musik, rima dan iramanya.

Bobbi DePorter dan Mike Hernacki (2001:38) mengatakan bahwa kedua belahan otak penting artinya, orang yang memanfaatkan kedua belahan otak ini juga cenderung 'seimbang' dalam setiap aspek kehidupan mereka. Belajar terasa sangat mudah bagi mereka karena mereka punya pilihan untuk menggunakan bagian otak yang diperlukan dalam setiap pekerjaan yang sedang dihadapi. Sebagian besar komunikasi diungkapkan dalam bentuk verbal atau tertulis, yang keduanya merupakan spesialisasi otak kiri, bedang-bidang pendidikan, bisnis, dan sains cenderung berat ke otak kiri. Sesungguhnya, jika peserta didik termasuk kategori otak kiri dan tidak melakukan upaya tertentu memasukkan beberapa aktivitas otak kanan dalam hidup, ketidak seimbangan yang dihasilkannya dapat mengakibatkan peserta didik stress dan juga kesehatan mental dan fisik yang buruk.

Untuk menyeimbangkan kecenderungan peserta didik terhadap otak kiri, perlu dimasukkan musik dan estetika dalam pengalaman belajar. Semua itu menimbulkan emosi positif, yang membuat otak peserta didik lebih efektif. 
Bila peserta didik sedang serius belajar matematika, yang tentunya dengan menggunakan otak belahan kiri, kadang-kadang otak kanan suka menggangu dengan kemampuan imaginasinya. Sehingga otak kanan memikirkan atau menghayal hal-hal lain diluar yang dihadapi. Jika aktivitas otak kanan ini tidak disalurkan maka akan terus menggangu otak kiri untuk bekerja. Untuk menyeimbangkan kerja otak belahan kanan tersebut dirangsang dengan mendengarkan musik kelasik tertentu, sehingga kedua belahan otak sama-sama bekerja. Bahkan dalam teori pengelolaan pembelajaran modern, seperti Quantum Learning, Accelerated Learning, Super Learning, Revolusi of Learning, dan yang lainnya 'penggunaan musik kelasik tertentu' sebagai background, sangat dianjurkan dalam proses pembelajaran.

Tentang musik dapat mempengaruhi emosi secara positif, ternyata bukan hanya para ahli psikologi saja yang menganjurkan, hingga tokoh sufi sekalipun, seperti Imam Gojali menyatakan bahwa musik tertentu dapat menggerakkan hati. Dalam Ikhtisar Ihya Ulumiddin (2002:169), terdapat sebuah judul "sama' dan Al-Wajd", artinya mendengarkan musik dan menemukan sesuatu. "Kami katakan, sama' adalah mendengar suara yang baik yang berirama, difahami maknanya, dan sebagai penggerak kalbu". Dalam halaman lain (2002:172) beliau melanjutkan "Jadi, sama' memiliki pengaruh yang aneh (menakjubkan-pen). Siapa yang tidak tergerakkan oleh sama ', maka ia kurang akal, kurang normal, dan jauh dari ruhani”.

\section{APLIKASI DALAM PEMBELAJARAN DI SEKOLAH DASAR}

Upaya untuk memperbaiki dan memperbaharui proses pengajaran di jenjang sekolah dasar yakni pada pembelajaran tematik. pendidik dapat mengkombinasikan dengan pembelajaran berbasis ramah otak. Adapaun hakikat dari pembelajaran tersebut adalah sebagai berikut.

\section{Membangun persepsi siswa; Hidup di saat ini}

Langkah awal yang harus pendidik lakukan adalah menyadari bahwa profesi pendidik adalah pilihan kita. Peran kita sebagai pendidik sangat penting. Kita dinantikan oleh banyak anak yang akan hidup di masa depan 
dengan berbagai tantangan zaman. Dan kita harus sadar bahwa hidup saat ini merupakan suatu keniscayaan masa depan yang penuh dengan perubahan.

\section{Berpandangan Positif Terhadap Peserta Didik}

Niat kuat seorang pendidik atau kepercayaan akan kemampuan dan motivasi peserta didik harus terlihat sangat jelas. segala apa yang ada pada diri semuanya berbicara. Peserta didik "menangkap" pandangan anda lebih cepat dan akurat daripada mereka "menangkap" apapun yang diajarkan. Berlatihlah untuk mengubah pandangan dengan membayangkan angka 10 tercetak pada setiap kening siswa. Atau lebih mudah lagi kita melihat bintang emas pada setiap kening, seolah-olah mereka adalah peserta didik cerdas atau top. Dalam buku Education Of Possibility, Renate Nummela Caine dan Geoff menyatakan bahwa keyakinan pendidik akan potensi peserta didik dan kemampuan semua peserta didik untuk belajar dan berprestasi merupakan suatu hal yang sangat penting untuk diperhatikan. Pendidik harus yakin bahwa tidak ada peserta didik yang bodoh, semua peserta didik cerdas dan yang membedakan adalah bidang kecerdasan masing-masing.

\section{Menanamkan AMBAK}

Peserta didik dapat mengikuti pelajaran apabila mereka tahu manfaat bagi kehidupan mereka. Munculkan aplikasi-aplikasi dari ilmu dan kegunaan ilmu di masa depan seperti ditempat kuliah, bekerja dan sebagainya.

\section{Mengajar Sesuai Dengan Prinsip Kerja Otak}

Dalam pembelajaran di sekolah dasar dapat dilakukan dengan mengacu pada prinsip kerja otak. Terdapat 4 (empat) prinsip kerja otak pada diri peserta didik. Keempat prinsip kerja tersebut yakni; a) Memulai menceritakan dengan penemuan-penemuan baru, b) Memberikan waktu jeda, c) Mengiringi belajar dengan music klasik. Dan d) Belajar dengan melibatkan emosi peserta didik.

\section{Mengajar Sesuai Dengan Tipe Belajar}


Bekal seorang pendidik ketika menanamkan dirinya_Quantum Teacher_bukan lagi gambaran kemampuan akademis peserta didik melainkan pendidik harus mengetahui tipe belajar peserta didik. Ada tiga tipe belajar peserta didik

a. Visual. Modalitas ini mengakses citra visual yang diciptakan maupun yang diingat seperti warna, hubungan ruang, potret mental.

b. Auditorial. Modalitas ini mengakses segala jenis bunyi dan kata yang diciptakan maupun diingat seperti music, nada, irama, dialog internal dan suara menonjol.

c. Kinestetik. Modalitas ini mengakses segala jenis gerak dan emosi yang diciptakan maupun diingat. Gerakan, koordinasi, irama tanggapan emosianal dan kenyamanan fisik menonjol disini.

\section{Mengajar Dengan Menggunakan Media}

Media pengajaran yang dapat kita gunakan sesuai modalitas para murid :

a. Untuk modalitas visual alat yang digunakan adalah poster, OHP, slide proyektor, vcd, televisi dan sebagainya.

b. Untuk modalitas auditorial alat yang digunakan adalah tape recorder, haed phone, ceramah/bercerita, belajar lewat lagu dan sebagainya.

c. Untuk modalitas kinestetik alat yang digunakan adalah praktikum (alat-alat praktik), simulasi belajar dengan gerak dan sebagainya.

\section{Mengajar Cara Belajar}

Kelemahan dari metode pengajaran selama ini adalah menjadikan pendidik sebagai satu-satunya sumber pembelajaran. sebaiknya peran pendidik hanya sebagai fasilitator, biarkan peserta didik berenang dilautan ilmu dengan berbagai gaya dan kecepatannya. Karena pendidik sudah terbiasa menjadi sumber satu-satunya, akhirnya peserta didik bersifat fasif tidak mampu berinisiatif dan tidak memiliki keterampilan belajar. Sebaiknya pendidik mengajarkan cara belajar agar peserta didik dapat belajar dengan kecepatan tinggi dengan melebihi kemampuan (ilmu) pendidiknya. Cara belajar yang harus pendidik berikan kepada peserta didik adalah tehnik 
membaca cepat, tehnik mencatat tingkat tinggi, mind mapping, catat tulis susun, teknik menghafal.

\section{Memberi pengalaman "Aha"}

Banyak peserta didik yang terhempas tertutup harapannya untuk menguasai pelajaran, karena mereka prustasi, belum apa-apa kesulitan bertengger di depan mata. Bagaimana peserta didik dapat keluar dari himpitan psikologis seperti ini??

Pengalaman "Aha" artinya para murid diberi pengalaman dapat mengerjakan atau berhasil dengan nilai yang baik, walaupun soal yang diberikan merupakan setingan memunculkan kegembiaraan/rasa .

\section{Menciptakan Feed Back (jalin hubungan emosional dengan siswa)}

Sangat baik jika pendidik menciptakan hubungan erat dengan murid, tersenyum ketemu murid, menyapa duluan, member selamat kepada murid yang ultah, memberi nasihat, memanggil mereka dengan kesayangan di rumah, memberi hadiah kepada yang berhasil. Pada saat istirahat sebaiknya pendidik tinggalkan meja kerja, dan keluar dari ruangan pendidik dan bergabung bersama mereka dengan memainkan alat music atau sekadar ngobrol-ngobrol. Dengan kedekatan yang diwarnai saling percaya dan saling menghormati, pendidik dapat memahami langkah apa yang harus dilakukan untuk membantu mereka. Tanamkan pada diri kita bahwa pendidik dan murid adalah mitra. Tak ada salahnya pendidik meminta saran (feed back) dari murid demi kemajuan metode mengajar kita.

\section{Menata Lingkungan Belajar Mengajar.}

Pendidik yang kreatif, pendidik akan mengerahkan seluruh potensi diri dan lingkungannya untuk menciptakan suasana learning is fun. Pertama yang dapat diatur adalah bangku tempat duduk anak-anak diatur sedemikian sesuai dengan acara belajar, tidak monoton hanya menghadap kedepan. Kemudian di dalam kelas sangat baik jika ditata ada tumbuhan hidup untuk meningkatkan volume oksigen di dalam ruangan yang berguna bagi makanan otak, aroma-aroma yang dapat meningkatkan 
kecerdasan 30\% memberikan ketenangan dan rileksasi, dan juga menyediakan hewan-hewan peliharaan yang dapat menumbuhkan rasa kasih sayang dan menghilangkan stress.

Kesepuluh hal tersebut apabila dilakukan dengan seksama akan melahirkan pembelajaran yang Ramah Otak. Ramah Otak tidak lain sebuah kultur belajar yang sangat efektif dan menyenangkan bagi siswa dan pendidik, sehingga tercipta proses pembelajaran yang sangat berenergi. Selama ini, proses belajar masih secara alami dan memaksa hanya otak kiri kita, sehingga yang muncul adalah kejenuhan, bosan, dan tidak menyenangkan. Belajar secara Ramah Otak menuntun kita untuk lebih mengoptimalkan bagaimana otak kita bekerja untuk belajar. Karena satusatunya mesin untuk belajar adalah otak. Kalau otak manusia dilibatkan secara keseluruhan dan termasuk jiwa dan raga kita, maka akan terjadi percepatan belajar yang tidak akan kita duga dari sebelumnya (mungkin pemahaman akan meningkat cepat seperti halnya kecepatan cahaya). Tentunya konsep Ramah Otak ini menjadi bersahabat dengan metode pembelajaran quantum, karena Ramah Otak terlahir dari bagaimana seharusnya kita belajar dengan menggunakan seluruh otak kita dengan sikap belajar yang menyenangkan.

\section{E. PENUTUP}

Pembelajaran pada jenjang sekolah dasar memerlukan model pembelajaran yang berbasis ramah otak. Pembelajaran yang dapat diterima sesuai dengan kapasitas kemampuan otak peserta didik. Kenyamanan peserta didik dalam belajar memberikan kemudahan pada siswa itu sendiri dalam menerima materi. Materi pembelajaran dapat diterima dengan baik, ketika psikologis peserta didik tertata dengan baik. Psikologis peserta didik salah satunya yakni tergantung pada kondisi otak yang berperan dalam mengatur seluruh aktifitas pisik maupun psikis. Kemampuan otak yang luar biasa dimiliki oleh peserta didik dapat dioptimalkan melalui kegiatan pembelajaran yang "luar biasa". Pembelajaran yang bermakna bagi peserta didik yang disajikan oleh pendidiknya dalam pencapaian tujuan pembelajaran. 
Penyampaian materi ajar oleh pendidik akan tersimpan dengan baik dalam memori jangka panjang, jika pembelajaran tersebut mudah dicerna oleh peserta didik. Pembelajaran tidak sebatas formalitas penyampaian pesan ilmu pengetahuan, melainkan untuk mengeksplor seluruh kemmpuan peserta didik dengan maksimal. Maka dengan keterlaksanaan pembelajaran ramah otak di jenjang pendidikan dasar diharapkan dapat mencapai tujuan pembelajaran yang efektif. 


\section{DAFTAR PUSTAKA}

Agus Nggermanto. 2003. Quantum Qoutient (Kecerdasar Quantum). Bandung : Nuansa Cendekia, Cet. V

Al-Ghazali, Abu Hamid Muhammad ibn Muhammad. 2002. Ihya Ulumuddin. Semarang: Toha Putra

Danah Johar dan Ian Marshal. 2010. Spritual Capital Memberdayakan SQ di Dunia Bisnis. Bandung: Mizan Media Utama.

DePorter, Bobbi, dan Mike Hernacki. 2001. Quantum Learning: Membiasakan Belajar Nyaman dan Menyenangkan. Bandung: Kaifa

Dryden gordon. 2003. Revolusi cara belajar: The learning revolution bagian 1 . Kaifa: bandung

Goleman, Daniel. 2002. Working With Emotional Intelligence (terjemahan). Jakarta : PT. Gramedia Pustaka Utama

LeDoux J.E. 2002. Synaptic Self: How Our Brains Become Who We Are. New York : Viking.

Madarij as-Salikin baina Manazil Iyyaka Na'budu wa Iyyaka Nasta'in, karya Imam Ibn al-Qayyim, tahqiq Muhammad Hamid al-Faqi, Beirut: Dar alKitab al-'Arabi, 1393/1973

Meier, Dave. 2002. The Accelerated Learning Handbook Panduan Kreatif dan Efektif Merancang Program Pendidikan dan Pelatihan. Bandung : Kaifa.

Rakhmat, Jalaludin, 2004. Psikologi Komunikasi, Bandung : PT. Remaja Rosdakarya

Ramadhy, Sufyan. (2001). Bagaimana Mengembangkan Kecerdasan?. Sarana Panca Karya.

Syaikh abdurrahman bin hasan alu asy-syaikh. Terjemah fathul majid. Buana ilmu islami 